\title{
THE STATUS OF CHILDREN IN THE CONFLICT OF LAWS
}

George WrLFred Stumberg*

I T IS frequently assumed that principles of conflict of laws, at least as they are understood in the United States, make local domicil a necessary jurisdictional prerequisite to the creation by a state of any of those conditions of person which are customarily grouped together under the broad descriptive term "status." Consistent resort to this assumption for the solution of problems involving state power with respect to the status of children would require that when legitimacy ${ }^{2}$ is in issue, the circumstances be such as would legitimize under the law of the domicil at the time the circumstances occur, and that in the case of adoption ${ }^{3}$ or of custody, ${ }^{4}$ the judicial proceedings confirming the adoption or awarding custody take place at the domicil.

A reason which is frequently given for the assertion that power over status is, or should be, in the domiciliary state is that that state has a peculiar interest or concern in the status of its own citizens. ${ }^{5}$ Unfortunately, problems relating to permissible state control over legitimacy, adoption, and custody cannot be solved through resort to such a simple thesis. The legal relations which in the aggregate are designated by such terms as legitimacy, adoption, or custody, necessarily affect more persons than one. When the domicils of these individuals are in different states, consideration cannot be given simultaneously to the peculiar interests of all of the states involved. Furthermore, even though it were possible to weigh the interests of the several states for the purpose of determining the jurisdiction or jurisdictions having a predominant claim to power, the process of balancing and counter-balancing would, if state interests alone were taken into consideration, fail to make allowances for the interests of the child. And these latter interests, in view of national concern in matters relating to child welfare, would seem to be far more important than the somewhat

* Professor of Law, University of Texas.

I 2 Beale, Conflict of Laws 65I (I935); cf. Rest., Conflict of Laws § II9 comment c (I934); see in general Beale, The Status of the Child and the Conflict of Laws, I Univ. Chi. L. Rev. I3 (I933).

2 Rest., Conflict of Laws $\$ \S$ I37-4I (I934). $\quad 4$ Ibid., at $\$ \S$ II7-I8, I44-48.

3 Ibid., at $\S \S 4_{42-43}$.

5 Ibid., at § IIg comment c. 
ethereal claims to exclusive power by the different American states whose territorial limits have been fixed arbitrarily or by historical accident.

\section{LEGITIMACY}

Insofar as the legal systems prevailing in England and the United States are concerned, legitimacy is the oldest of our concepts of status affecting children. For a child to be legitimate at common law it is necessary that it be born or conceived in lawful wedlock. The Scotch and Continental legal systems have long made more liberal provisions, and in this country, and more lately in England, liberalizing statutes have been passed. Some of these statutes make legitimate a child born of a void marriage. Others provide for the legitimation of a child born out of wedlock through the occurrence after birth of some event, such as the intermarriage of the parents or the recognition and acknowledgment by a natural parent that the child is his. ${ }^{6}$

The radical differences between the English common law on the one hand and the Scotch and Continental law on the other, and the differences in statutory policy as between the several states of the United States, have given rise to a relatively large number of cases which furnish abundant judicial authority to support the proposition that legitimacy is a matter to be determined by reference to the law at the domicil. ${ }^{7}$ An assertion of legitimate character is not likely, however, to be an end in itself. The fact that the natural parents of a person who was born out of wedlock have later intermarried or have subsequently recognized him as their child, so that he has thus acquired legitimate standing according to the law of some particular state, while it may be of personal interest to him, has no juridical significance until that person makes a claim whose legal recognition depends upon his legitimate character. A variety of claims whose alleged legal validity might give rise to issues of legitimacy readily come to mind. Legitimacy could, for example, be an issue in a claim for support by a child against a parent, or in a claim by a parent to the custody of a child. But the claim which has been made in conflict of laws cases has been the right to succeed as a legitimate heir to the estate of a deceased parent or through that parent to the estate of a more remote ancestor or to that of a natural collateral relative. ${ }^{8}$

${ }^{6}$ See 4 Vernier, American Family Laws 8 et seq. (1936).

7 Fairly replete annotations of the decisions are available in 73 A.L.R. $94 \mathrm{I}$ (193 I) and in [IgI7 C] Ann. Cas. 537. See also 2 Beale, Conflict of Laws 704 (I935); Goodrich, Conflict of Laws 370 (2d ed. I938); Stumberg, Conflict of Laws 302 (r937).

${ }^{8}$ See notes $\mathrm{II}-\mathrm{I}_{4}$ infra for citations to cases. See note $\mathrm{I} 9$ infra for citations to cases involving a variety of claims by children adopted abroad.

Attention should be called to the fact that provision is often made for inheritance by illegitimate children. Whether an illegitimate child can inherit and from whom is, of course, a matter 
When litigation involving the right to succession calls for the application of principles of conflict of laws, the almost universal judicial reaction is to refer to the law at the situs in the case of land' and to the law at the domicil of the decedent at the time of death in the case of movables. ${ }^{\text {xo }}$ Under the laws of descent and distribution as they exist in the different states, heirship may depend entirely upon the legitimate character of the claimant or legitimacy may carry with it a preferred standing. Establishment of legitimacy may, therefore, become important in that it may be the means by which the claimant can acquire an identification tag that will permit him to participate in the distribution of a decedent's estate.

Since the matter of heirship is involved in this type of litigation, there is no logical reason why the usual formulae applicable to succession on death to movable and immovable property should not be employed to ascertain whether the claimant comes within the proper description of legitimate heir so that, were it thought to be desirable or expedient to do so, legitimacy could be made to depend upon the law at the decedent's domicil in the case of distribution of movables and upon the law at the situs in the case of descent of land. A court sitting at the actual location of property has the power to determine who is entitled to receive it through succession on death, and a decision by it that a claimant must wear the badge of legitimacy as locally defined would, insofar as it affects title to local property, have to be recognized as effective elsewhere. ${ }^{\text {II }}$ The power of

of succession and is therefore controlled by the law at the situs in the case of immovables and by the law of the decedent's domicil in the case of movables. Moen v. Moen, I6 S.D. 2IO, 92 N.W. I3 (IgO2); Van Horn v. Van Horn, xo7 Ia. 247, 77 N.W. 846 (I899).

A question as to what law determines legitimate character sometimes arises in connection with the use of the word "children" in a will, as where there is a devise or bequest to the children of $A$, or to such children of $A$ as he shall appoint or name in his will. If $A$ has a child who, although born out of wedlock, has been legitimized by some subsequent act, an issue may be raised as to whether it comes within the terms of the original devise or bequest. In Holloway v. Safe Deposit \& Trust Co., I5I Md. 32I, I34 Atl. 497 (I926), writ of error dismissed 274 U.S. 724 (I927), it was held that Nevada law, as that of the domicil of the father, fixed the character of the child who was allowed to take under the terms of the will, although the will as a whole was controlled by Maryland law. The problem in a case like this seems, in reality, to be one of construction of wills, i.e. one of determining whether the words used by the testator include children legitimized according to some foreign rule of law. Grey v. Stamford, [I892] $3 \mathrm{Ch}$. 88; Boyes v. Bedale, I Hem. \& M. 798 ( 1863 ); In re Goodman's Trusts, I7 Ch. D. 266 (I88r).

9 Clarke v. Clarke, I78 U.S. I86 (Ig00); Hills v. Hansen, I76 Cal. 232, I68 Pac. 20 (I9I7); Appeal of Silberman, ro5 Conn. I92, 134 Atl. 778 (1926); Brandeis v. Atkins, 204 Mass. 47x, go N.E. 86I (xgro); cf. Rest., Conflict of Laws $\$ 245$ (I934).

ro Ennis v. Smith, 14 How. (U.S.) 399 (1852); Caruso v. Caruso, Io6 N.J. Eq. I3o, I48 Atl. 882 (I930); In re Chappell's Estate, 124 Wash. x28, 2 I3 Pac. 684 (I923); cf. Rest., Conflict of Laws $\$ \$ 303,306$ (1934).

Ir In some of the cases the courts appear to have construed statutes providing for legitimation through some subsequent event as statutes of inheritance. Hall v. Gabbert, 213 IIl. 208, 
legislatures or courts to exclude from succession to local property claimants who do not conform to local requirements for legitimate heirship has been frequently recognized, ${ }^{x 2}$ and the exercise of power in this respect, even though it may result in the exclusion of a claimant who is legitimate according to the standards of some foreign system of law, does not conflict with notions of due process and full faith and credit. ${ }^{x_{3}}$

As has already been intimated, most courts have not exercised their power so as to require a claimant to the decedent's estate, or a portion of it, to be legitimate according to the standards of what they recognize to be the proper law to control the succession. What they have ordinarily done has in effect amounted to a separation or segregation of the issues. Ability of the claimant to inherit, whether as a legitimate or as an illegitimate child, has been treated as a matter within the scope of the formulae controlling the succession; but legitimacy has been dealt with as a matter concerning the classification of persons according to their legitimate or illegitimate status, and as subject, therefore, to other considerations. The domiciliary law has been regarded as the proper law to control, and when the domicil of the parent and that of the child have been different, operative effect has been given the law of the domicil of the parent at the time of the occurrence of the events alleged to have legitimized the child. ${ }^{14}$

A possible explanation of this usual judicial reaction is that it has a cer-

72 N.E. 806 (1904); Franklin v. Lee, 30 Ind. App. 3I, 62 N.E. 78 (I90I); Sneed v. Ewing, 5 J. J. Marsh (Ky.) 460 ( $x 83$ I); cf. Wolf v. Gall, 32 Cal. App. 286, I63 Pac. 346 (Igr6); and cases cited note $x 2$ infra. A requirement that an alleged heir be legitimate in conformity with the rules governing the succession does not violate the Constitution of the United States. Olmsted v. Olmsted, I90N.Y. 458,83 N.E. 569 (I908), aff'd 2 I6 U.S. 386 (I9I0).

${ }^{12}$ A good example is the construction given the so-called English Statute of Merton in Birtwhistle v. Vardill, 7 Clarke \& F. 895 (1839) (a child born out of wedlock but legitimized in the domicil of the parents, Scotland, through their subsequent marriage could not inherit English land). But compare the rule as to personality. In re Goodman's Trusts, I7 Ch. D. 266 (I88I); cf. Lingen v. Lingen, 45 Ala. 4ro (I87r); Williams v. Kimball, 35 Fla. 49, I6 So. 783 (I895); Smith v. Derr's Adm'rs, $34 \mathrm{~Pa}$. I26 (I859). But cf. In re Estate of Oliver, r84 Pa. 306 , 39 Atl. 72 ( 1898$)$.

${ }_{3}$ Olmsted v. Olmsted, Igo N.Y. $45^{8}, 83$ N.E. $5^{69}$ (rgo8).

14 Moore v. Saxton, 90 Conn. 164, 96 Atl. 960 (I9r6) (the law of the domicil of the parents at the time of birth controls the legitimacy of the issue of a void marriage); Rest., Conflict of Laws $\S x_{3} 8$ (I934); cf. Green v. Kelley, 228 Mass. 602, II8 N.E. 235 (IgI8), where the court speaks of the controlling effect of the "Taw of the domicil of the person in question."

As to the effect of legitimation as the result of the subsequent intermarriage of the parents see Adams v. Adams, I 54 Mass. 290,28 N.E. 260 (I89I); Smith v. Kelly, 23 Miss. I67 (I85I); Miller v. Miller, gI N.Y. 3 I5 ( 1883 ).

As to the legitimation through other subsequent events see Blythe v. Ayres, 96 Cal. 532, 3I Pac. 915 (1892) (the domicils of the father and child were different; the law of the father's domicil controlled so as to legitimize); Irving v. Ford, r83 Mass. 448, 67 N.E. 366 (Igo3) (the father's and not the child's domiciliary law governed so that the child was treated as illegiti- 
tain amount of tradition behind it. The doctrine that the law of the domicil determines legitimacy had the support of Justice Story ${ }^{15}$ and before him of a number of the Dutch and French statutists who regarded legitimacy as something pertaining to persons and, as such, entitled to extraterritorial recognition at a place other than the usual abode of the persons immediately affected by the acts of the parents. ${ }^{16}$ Besides, the idea that legitimate character should as a matter relating to persons be controlled by considerations different from those which determine the classes of individuals who are to succeed as heirs has a subtle attraction. Since the domicil of the natural parent, because he is likely to be sui juris, is usually easy to determine, reference of the child's legitimacy to the law of that place ordinarily calls for the use of relatively simple thought processes. ${ }^{\mathbf{T}}$ Once the domiciliary state is ascertained, the legitimacy rules of that state automatically come into operation. The occurrence of the events which bring them into operation is within the control of the parent; so, it seems natural enough to refer the question of the effect of the events to the law of the parent's domicil at that time, that being normally the place where the parent then has his actual residence.

mate). See also In re Presley, Ix3 Okla. I6o, 240 Pac. 89 (I924), and Eddie v. Eddie, 8 N.D. 376,79 N.W. 856 (r899), in both of which there was a change of domicil (after the act) to a state the laws of which made the child legitimate. The law of the parent's domicil at the time of the alleged legitimizing act was held to control so that the children were treated as illegitimate.

Prior to the Legitimation Act of I926, the English courts required that the child be susceptible of the legitimation under both the law of the father's domicil at the time of birth and that of his domicil at the time of the act. In re Grove, 40 Ch. D. 2 I6 (I887); cf. Succession of Caballero, 24 La. Ann. 573 (I872); Ross v. Ross, I 29 Mass. 243 (I880); Miller v. Miller, 9r N.Y. 3 I5 ( 1883 ); Rest., Conflict of Laws $\S \S 139-4 \circ$ (r934), where a distinction is made between retroactive legitimation, i.e. back to the birth of the child, and legitimation from the time of the act.

Is Story, Conflict of Laws $\S 93$ et seq. (8th ed. r883). Story's position (at page I25) was that even the interpretation of the Statute of Merton (see note $x 2$ supra) was unsound because the statute was intended to apply only to heirs born in England.

${ }^{6} \mathrm{This}$, at least, was the conclusion of Story, who discussed at length the opinions of the French and Dutch jurists. Story, Conflict of Laws I22 (8th ed. 1883).

${ }^{17}$ All the cases examined involved a claim by a child to legitimate relationship to the father. The domicil of a person who is sui juris is ordinarily at the place where he makes his home. Rest., Conflict of Laws $\S$ I2 (I934). In none of the cases was the domicil of the father questioned. What judicial reaction would be in a case where the domicil of the parent, i.e. the natural father or mother, is only a technical one, i.e. by operation of law and unaccompanied by actual residence, would be difficult to predict. If a parent attempted to succeed to the estate of the deceased child or to assert some other claim respecting the child, would emphasis be on his or the child's domiciliary law? See Rest., Conflict of Laws § 137 (I934), leaving open the possibility that the law of the child's domicil can control. 


\section{ADOPTION}

The term legitimacy, while its consequences may vary according to state or country, has long been a part of the legal vocabulary of at least those jurisdictions whose legal systems are of European origin. Adoption is, however, a statutory innovation in those of our American states, the legal background of which lies in the common law of England. So, consequently, no provision for adoption was formerly made in a large number of American states, and even now with the universal enactment of adoption statutes ${ }^{18}$ there are sometimes differences in local legal effect, particularly with respect to the extent of the ability of an adopted child to inherit.

Most but not all of the cases involving recognition of foreign adoption have grown out of claims made by adopted children to participate in the distribution and descent of decedents' estates. When the rules with respect to succession have been substantially the same at the forum as abroad, a large majority of the courts have experienced no difficulty in recognizing the effectiveness for local purposes of the foreign proceedings. ${ }^{\text {I9 }}$ A few have, however, taken the position that a child adopted in another state may not inherit local land; some have so held even though legislative provisions at the situs permitted inheritance by children locally adopted. Whether adopted children may inherit, and from whom, would seem to be clearly matters of local policy; and if the courts at the situs of property have come to the conclusion, because of the absence of a statute permitting it or because of their construction of the local adoption and inheritance statutes, that the legislative policy at the situs is such as to preclude succession on death by children adopted abroad, neither principles of con-

${ }^{88}$ An adoption statute was not enacted in England until rg26. For a short general discussion of adoption see Brosnan, The Law of Adoption, 22 Col. L. Rev. 332 (rg22). Adoption statutes now exist in all American jurisdictions. 4 Vernier, American Family Laws 279 (r936).

19 Cf. Woodward's Appeal, 8I Conn. I52, 70 Atl. 453 (Ig08); Van Matre v. Sankey, I48 III. 536, 36 N.E. 628 (1893); Gray v. Holmes, 57 Kan. 21 7, 45 Pac. 596 (1896); Pyle v. Fischer, 278 Ky. 287, I28 S.W. (2d) 726 (I939); Finley v. Brown, I22 Tenn. 316, I23 S.W. 359 (I909); Martinez v. Gutierrez, 66 S.W. (2d) 678 (Tex. Com'n App. 1933). The foregoing cases involved intestate succession, but other claims based on foreign adoption have been before the courts. In Dulfon v. Keasbey, IIx N.J. Eq. 223, I62 Atl. ro2 (1932), for example, the matter in issue related to the construction of a will. In Ex parte Osborne, 205 N.C. 7I6, I72 S.E. 49I (I934), habeas corpus proceedings were brought to recover custody of a child adopted in another state; cf. Moore v. Smith, 228 Ky. 286, I4 S.W. (2d) I072 (1929) (semble); Victory Sparkler \& Specialty Co. v. Gilbert, I60 Md. r8r, I53 Atl. 275 (r93I) (semble) (claim made for compensation to adoptive parent for death of the child). 
flict of laws nor of full faith and credit under the Constitution require a contrary decision. ${ }^{20}$

Local variations of policy with respect to succession by adopted children sometimes give rise to situations in which the law which is ordinarily regarded as proper to control the succession differs from the rules in force where the adoption proceedings took place insofar as the ability of an adopted child to inherit from persons other than his adopted parents is concerned. There are decisions which permit the child to inherit only in conformity with the law controlling the adoption..$^{2 x}$ But cases to the effect that the child can inherit as permitted by the law which governs the succession $^{22}$ seem to reach a more consistent result since the question before the court is in reality whether the claimant as an adopted child is within a class permitted to succeed as heir, not only to the property of his adoptive parents, but also to that of their blood relatives. In other words, the differences in the laws of the two jurisdictions seem to be due to differences in policy with respect to succession by adopted children, rather than to differences in policy with respect to adoption.

In the situations to which reference has just been made, the courts have either found or assumed that the foreign proceedings so operated as to transfer the parental relationship from the natural to the adoptive parent. But attention should be called to the fact that statutory provision is occasionally made for what may be called adoption, when in reality the preexisting relationship of parent and child is left undisturbed so that the only effect of the proceedings is to make the child "an heir by adoption." In a relatively recent Arkansas case ${ }^{23}$ involving the effect of adoption un-

${ }^{20}$ Hood v. McGehee, 237 U.S. 6 Ix (I9I5) (exclusion of a child adopted abroad from participation in a local estate does not violate the Constitution of the United States); Brown v. Finley, 157 Ala. 424, 47 So. 577 (1908); Mott v. First Nat'l Bank, 98 Fla. 444, x24 So. 36 (1929);

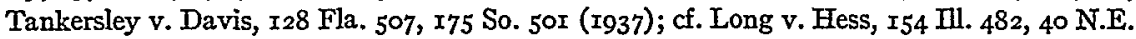
335 (1895); Fisher v. Browning, I07 Miss. 729, 66 So. I32 (1914). But cf. Brewer v. Browning, Ix5 Miss. 358 , 76 So. 267 (I917).

In Frey v. Nielson, 99 N.J. Eq. I35, I32 Atl. 765 (1926), it was held that a child adopted outside that state may not inherit New Jersey land in spite of a New Jersey statute permitting locally adopted children to do so. The rule is contrary as to personality. In re Finkenzeller's Estate, I05 N.J. Eq. 44, $x_{4} 6$ Atl. 656 (I929).

Note that in some of the foregoing cases the adopted child was excluded from succession to local land on an analogy to the theory of Birtwhistle v. Vardill, 7 Clarke \& F. 895 ( 1839 ), discussed in note 12 supra.

${ }_{2 x}$ Cf. Boaz v. Swinney, 79 Kan. 332, 99 Pac. 621 (rgog). But cf. In re Riemann's Estate, I23 Kan. 718, 262 Pac. I6 (1927). See also Slattery v. Hartford-Connecticut Trust Co., Ix5 Conn. I63, I6x Atl. 79 (r932), and Allen v. Nickerson, 293 Mass. I36, I99 N.E. 482 (I936).

22 Anderson v. French, 77 N.H. 509, 93 Atl. I042 (I9I5). Cf. In re Riemann's Estate, I23 Kan. 7x8, 262 Pac. 16 (1927), and cases cited therein by the Kansas court.

${ }_{23}$ Shaver v. Nash, I8I Ark. IIr2, 29 S.W. (2d) 298 (1930). 
der a Texas statute of this kind, it was held that since the status of parent and child had not been created as the result of the proceedings in Texas, the claimant could not inherit in Arkansas, even though an adopted child could succeed there as heir.

In the comparatively few adoption cases not involving succession the courts have in effect decided or assumed that if the circumstances of the foreign adoption are such as to confer "jurisdiction" abroad, the foreign proceedings will be given the same effect at the forum as would local adoption. ${ }^{24}$ It can therefore be safely said that most of the American courts have come to the conclusion that if the foreign adoption in fact creates a parent-child relationship, it should not be refused recognition merely because of its foreign character. In this respect the adoption cases follow closely the pattern of the legitimacy cases, in most of which the courts have also recognized as effective at the forum legitimate character properly acquired in another state or country. ${ }^{25}$ Unlike the situation with respect to legitimacy, however, decisions involving the matter of "jurisdiction to adopt" are so diverse that it would be impossible to point to any one standard or criterion which has been applied with even only a fair degree of uniformity in designating the boundaries of the circumstances which must exist abroad in order for the foreign adoption to be entitled to recognition.

The problem of jurisdiction has been dealt with in a number of cases involving claims by children adopted abroad. In addition, the fact that statutes regulating adoption now provide for judicial participation in the proceedings ${ }^{26}$ has resulted in numerous decisions involving local problems as to "jurisdiction to adopt." These decisions, while they are confined to questions relating to local exercise of judicial power, are also important since they indicate as argumentative authority what the attitude of the same courts would probably be when called upon to recognize the local effectiveness of a foreign adoption.

It has been said that "judicial jurisdiction" to adopt "would seem to depend strictly on [the] common domicil of both parties, since the status of both is affected. ${ }^{\prime 27}$ If permissible jurisdiction must in reality depend upon

${ }^{24}$ See note Ig supra for cases illustrating the purposes for which foreign adoption has been relied upon.

${ }^{25}$ See note 14 supra.

${ }^{26}$ See Newbold, Jurisdictional and Social Aspects of Adoption, II Minn. L. Rev. 605, 62I (I927), where it is stated that four states, Alabama, Iowa, Texas, and Vermont, still provided for adoption by contract in I927; 4 Vernier, American Family Laws 279 (Supp. 1938), where it is said that "formerly a number of jurisdictions permitted adoption by means of a formal instrument, without court proceedings of any kind, but these provisions have gradually been repealed." Cf. ibid., at 293: "The statutes are uniform in requiring judicial proceedings."

272 Beale, Conflict of Laws 73r (I935). See Newbold, op. cit. supra note 26. 
domicil, supposedly on a theory that status can be localized at the domicil or that only the state of the domicil can have an interest in status, complete consistency would require a position to the effect that judicial power with respect to adoption can only be exercised by a court sitting in a state which is the common domicil of the child, of its adoptive parents and of both its natural parents, since the proceedings have an effect not only upon the status of the child with respect to the adoptive parents, but also upon its status with respect to the natural parents. In other words, since the status of the child, of the natural parents, and of the adoptive parents is involved, the domicil-jurisdictional requirement would have to be present as to all.

But to require that all the persons concerned have a common domicil would have serious disadvantages, since such a requirement would often render it impossible for a contemplated adoption to take place. A nonresident, for example, would be unable to adopt in spite of the fact that the policy of a particular state might be such as to enable him to do so, and one could quite readily imagine situations where adoption by a nonresident would be to the best interests of the child. In any event, there is nothing in the cases to indicate that the courts require that all the persons affected by the adoption be domiciled in the state where the proceedings take place.

Statutes frequently require the adoptive parent to be a resident, ${ }^{28}$ and when this has been the case, it has been held that the child need not be domiciled in the state. ${ }^{29}$ On the other hand, there are a number of decisions to the effect that domicil on the part of the child alone suffices. ${ }^{30}$ In addition, the language of the courts is frequently such as to indicate that if either the adoptive parent or the child is actually residing in the state, the proceedings may take place there without regard to whether the residence is also a technical domicil. ${ }^{3 \mathrm{I}}$

${ }^{28} \mathrm{Cf}$. In re Sharon's Estate, I79 Cal. 447, I77 Pac. 283 (I9r8); Crocker v. Balch, I04 Tenn. 6, 55 S.W. 307 (rgoo); Platt v. Magagnini, xro Wash. 39, I87 Pac. 7 16 (rg20).

See also 4 Vernier, American Family Laws 293 (Supp. I938), where a summary of the statutory jurisdictional requirements is given. It is believed that the cases do not always bear out the statements there made to the effect that residence in adoption statutes means domicil. See note $3^{\text {I infra. }}$

29 Cf. Stearns v. Allen, I8 3 Mass. 404, 67 N.E. 349 (I903) (actual residence but not domicil of the child); Rizo v. Burruel, 23 Ariz. 137, 202 Pac. 234 (I92I); Taylor v. Collins, I72 Ark. 54r, 289 S.W. 466 (rg27); Woodward's Appeal, 8x Conn. r52, 70 Atl. 453 (rgo8).

$3^{\circ}$ Cf. Wolf's Appeal, Io Sad. (Pa.) I39, 13 Atl. 760 (I888); Succession of Caldwell, II4 La. I95, 38 So. I4० (I905); In re Voluntary Adoption, I30 Misc. 793, 226 N.Y. Supp. 445 (Surr. Ct. 1927); Van Matre v. Sankey, $x_{4} 8$ III. 536, 36 N.E. 628 (I893).

${ }^{3 x}$ According to the Restatement of Conflict of Laws ( $\left.\$ I_{42}\right)$ the status of adoption is "created" by the law of the state of the domicil of the adopted child, or by the law of the state of the domicil of the adoptive parent if that state has jurisdiction over the person having legal 
Upon first thought the decisions, some permitting the proceedings at the domicil of the adoptive parents and others at the domicil of the child, along with the frequent use of language indicating that residence alone suffices, could be taken as evidence of widespread conflict and confusion. Such a thought might, however, be based upon the assumption that a decision by which a court recognizes that the proceedings may be brought at a particular place necessarily excludes the possibility of the same court's holding that they may in the alternative be properly brought elsewhere. But an attempt to assign to the courts of a given state exclusive power over the legal relations included within such a nebulous concept as that of the status of parent and child is likely to proceed from a subconscious temptation to succumb to the fiction that the aggregate of the intangible legally recognized claims which are included within the parent-child relationship can be given an exclusive location at a designated place, some-

custody of the child or if the child is a waif and subject to the jurisdiction of the state. But a striking feature of the adoption cases is the liberality shown by most of the courts in sustaining or recognizing the existence of jurisdiction. Where statutes require that the adoptive parent be a resident, the term residence has been most liberally construed. In Wolf's Appeal, ro Sad. ( $\mathrm{Pa}$.) I39, I3 Atl. 760 (I888), for example, it was held to include temporary residence; the same result was reached in Van Matre v. Sankey, $x_{4} 8$ Ill. 536,36 N.E. 628 ( 1893 ). In both these cases, as well as in Succession of Caldwell, Ir4 La. 195, 38 So. 140 (IgO5) (in which the adoptive parent was a nonresident), the child was actually a resident of and apparently domiciled in the state where the proceedings took place. But in Stearns v. Allen, I83 Mass. 404, 67 N.E. 349 (rg03), and Woodward's Appeal, 8I Conn. I52, 70 Atl. 453 (rgo8), the child was not technically domiciled in the state where the proceedings took place. However, the adoptive parents were residents apparently having their domicil there.

While it would have to be conceded that none of the cases examined specifically holds that residence alone (i.e. without domicil of the adoptive parent or child) can be the sole basis for exercise of jurisdiction, the repeated emphasis upon the factor of welfare of the child, as well as the readiness of the courts in cases like those just mentioned to seize upon the substantial connection of either the adoptive parent or of the child with the state, would seem to indicate that residence even though not amounting to technical domicil would be treated as being sufficient to confer jurisdiction.

In this connection reference should be made to Waller v. Ellis, I69 Md. I5, I79 Atl. 289 (I935), in which it was stated that adoption proceedings may take place either at the domicil of the child or at the domicil of the adoptive parent; to Jensen v. Sorenson, 2rI Iowa 354, 233 N.W. 7 I7 (1930), in which a child who had been abandoned by the father and taken by an aunt with whom it was actually living was permitted to be adopted by the aunt at her domicil on (according to the Restatement of Conflict of Laws $\$ 33$ ) an erroneous theory that the child's domicil was at the home of the aunt; to In re Finkenzeller's Estate, I05 N.J. Eq. 44, I46 Atl. $65^{6}$ (I929), in which the New Jersey court recognized as valid an adoption in New York by a resident of New Jersey of a child who, at the time of the proceedings, was in a New York charitable institution, without going into the matter of the child's domicil; cf. Kugle v. Harpe, 234 Ala. 494, I76 So. 6I7 (I937) (the child seems to have been treated as domiciled with the adoptive parents to whom it had been relinquished prior to the adoption); Johnson v. Smith, 94 Ind. App. 6Ig, r80 N.E. I88 (r932); Greene v. Willis, 47 R.I. 375, $\mathrm{x}_{33}$ Atl. $65 \mathrm{r}$ (rg26); Cribbs v. Floyd, I88 S.C. 443 , I99 S.E. 677 (I938). 
what as a tangible thing is given its legal situs at the place where it is actually located so that the courts there alone may deal with it through in rem proceedings. Obviously, "status" has nothing in common with a physical "res." It can only have an imaginary form. To treat it as having a location in the sense in which a chattel or land does is merely a further bit of legal imagination.

Mention has already been made of the fact that the supposed interest of a state in its citizens is sometimes given as a reason for emphasis on domicil as a jurisdictional factor when status is involved. ${ }^{32}$ But it should be kept in mind that adoption affects a number of individual interests since the severance of the existing parental ties and the substitution of new ones brings about a change not only in the status of the child but also in that of the natural and adoptive parents. If the domicils of these persons should happen to be different, the interests of two, possibly three, states would be involved. But there is no satisfactory criterion by which these interests can be measured for the purpose of determining the state having the predominant claim to jurisdiction so as to make it possible to justify the position that its courts can alone entertain the proceedings. Consequently, the interest of a state in the status of its own citizens seems a weak foundation on which to build concepts of exclusive power.

Furthermore, emphasis on state interest fails to take into account the purpose of judicial intervention in adoption proceedings under modern legislation.

It was formerly the case in a large number of jurisdictions that adoption could take place as the result of some formal act which was likely to amount to little more than an adoption agreement between the natural and adoptive parents. But judicial approval of a proposed adoption is now required in all the states; and in a large number of them there must be a preliminary, independent investigation by some social agency such as a probation officer or welfare worker. ${ }^{33}$ The change in attitude toward the procedure to be followed in adopting a child has grown out of the thought that adoption is not always desirable for either the child or the adoptive parents. The background, environment, and temperament of the child, or of the adoptive parents, may be such as to make it undesirable for the existing conditions to be changed in the proposed manner. The purpose, then, in providing for closer investigation under judicial supervision is to assure for the child, as far as possible, a proper environment. ${ }^{34}$

32 See note 5 supra. ${ }^{33}$ See 4 Vernier, American Family Laws 294 (I936).

34 For typical cases in which particular emphasis was put upon the thought that a court's primary function is to protect the interests of the child, see Stearns v. Allen, 783 Mass. 404, 67 
Since all the states now permit adoption, there is no longer any good reason for refusing to give local effect to a foreign adoption merely because of ideas of local public policy. Also, for the same reasons, as between the states which might have claims to jurisdiction because their citizens are involved, it should make very little difference where the proceedings take place as long as they are had under circumstances which permit opportunity for a fair investigation for the purpose of determining the social desirability of the proposed adoption. A court sitting at the actual residence of the child, even though that may not be its technical domicil, is pre-eminently in a position to make the proper investigation. It can readily inquire into the child's environment, and the filing of the petition by the adoptive parents gives it the necessary power over them to make it possible to go into the matter of their fitness to become the child's foster parents. On the other hand, a court at the residence of the adoptive parents is able to investigate the environment into which the child will go should the adoption be approved. If in addition the child is present, jurisdiction over it and over its custodian make it possible to investigate the child's environment, background and temperament. Thus, this court also can protect the child against an undesirable change in parental control.

It is not improbable that the wide variations in the judicial decisions reflect a desire on the part of the courts to give to the term "jurisdiction to adopt" a sufficiently broad content to enable them to recognize as effective at the forum a foreign adoption as long as the conditions abroad were such as to make adequate investigation possible. Certainly the decisions as they now stand do not preclude definite judicial acceptance of such a broad jurisdictional concept.

\section{CUSTODY}

Although custody proceedings are usually brought as an incident to a suit for divorce, ${ }^{35}$ jurisdiction to make the award involves considerations which are quite different from those involved in jurisdiction to dissolve a marriage. Also, the action of the court is not as far-reaching as that in adoption proceedings, since the judicial award or decree does not pretend

N.E. 349 (I903); Woodward's Appeal, 8I Conn. I52, 70 Atl. 453 (I908); Wolf's Appeal, to

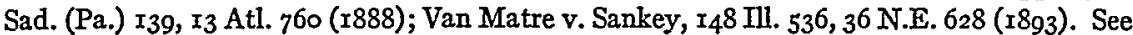
also 4 Vernier, American Family Laws 298 et seq. (r936). Apparently, according to the table given by Vernier, the statutes of practically all the states emphasize the welfare and interests of the child as an end to be attained.

35 According to 4 Vernier, American Family Laws I8 (I936), all states have some sort of legislation providing for the removal of a child from parental control under certain circumstances. But contests between parents upon divorce or separation have been the usual sources of litigation. 
to declare generally that the party against whom the award is made ceases to be the legally constituted parent. Recognizing that after the dissolution of the marriage both parents cannot simultaneously control the child, the court, when the proceedings are an incident to a suit for divorce, gives one of them the exclusive right to control, with the other sometimes having the privilege of seeing the child at stated times, or one is given the control during a specified period out of each year, with the other having control for the remainder of the time. The award determines the right to custody on the basis of existing facts only. Consequently, should there be a change in conditions, the decree may be modified. Since new personal obligations as between the parents, and sometimes as to third parties, are imposed, and since these obligations are subject to subsequent control, the court's action, irrespective of the words used in making the award, has the earmarks of the ordinary processes of a chancellor in equity. Therefore, unless special reasons exist for disregarding the equitable aspects of the decree, there would, under the normal conceptions of jurisdiction in equity, have to be personal jurisdiction of the parties.

Occasional decisions have emphasized the in personam nature of custody proceedings. ${ }^{36}$ But considerable authority can be found for the proposition that judicial power may be exercised at the domicil of the child without regard to jurisdiction in personam, ${ }^{37}$ and some of it can be

${ }^{6}$ De la Montanya v. De la Montanya, Ir2 Cal. Ior, 44 Pac. 345 (1896). In this case the children had been removed by the father from California just before divorce proceedings were brought. The father's domicil was in that state as was the mother's. California was unquestionably the domicil of the children. In the course of the opinion denying the mother's petition for custody, the court stated that if the children had been in the state and the father had been served with summons, jurisdiction would have existed. It was also indicated, however, that jurisdiction might have existed without service of process, if the children had been present. Cf. Boens v. Bennett, 20 Cal. App. (2d) 477, 67 P. (2d) 7x5 (r937); Anderson v. Anderson, 74 W.Va. r24, 8 I S.E. 706 ( $\mathrm{r}_{9} \mathrm{I}_{4}$ ); the dissenting opinion in Duryea v. Duryea, 46 Idaho 5I2, 269 Pac. 987 (I928); Steele v. Steele, I52 Miss. 365, II8 So. 721 (I928) (there was no jurisdiction "when neither the defendant nor the children were within the jurisdiction" of the foreign court).

37 Custody cases are collected in 70 A.L.R. 526 (I93I) and 72 A.L.R. 44I (I93x). See also Goodrich, Custody of Children in Divorce Suits, 7 Corn. L.Q. I (I921); Rest., Conflict of Laws $\S \S \mathrm{x} 7, \mathrm{II} 8, \mathrm{I}_{44}-48$ (1934). The following are typical custody cases upholding the thesis that there is jurisdiction at the domicil of the child: Duryea v. Duryea, 46 Idaho 5I2, 269 Pac. 987 (r928); Wear v. Wear, r30 Kan. 205, 285 Pac. 606 (I930); State ex rel. Larson v. Larson; Igo Minn. 489, 252 N.W. 329 (I934); Cf. Minick v. Minick, III Fla. 469, I49 So. 483 (I933); Bourn v. Hinsey, $I_{34}$ Fla. 404, I83 So. 6I4 (I937); Person v. Person, I72 La. 74O, I35 So. 225 (I93I), in all of which jurisdiction at what was found to be the child's domicil was recognized to exist although the child was apparently not physically present in the decree-granting state.

The domicil of a child is normally the same as that of its father. Attention should be called, however, to the fact that a number of courts hold that upon the separation of the parents, the domicil of a child is with the parent with whom it in fact resides, so that the domicil may be with the mother. Wear v. Wear, I30 Kan. 205, 285 Pac. 606 (I930); Elliot v. Elliot, I8I Ga. 545, 
construed as requiring that the proceedings be brought there ${ }^{38}$ The underlying theory, like that at times advanced when legitimacy and adoption are involved, seems to be that custody is a matter of status-in this case the child's-and that the domiciliary state, since it is primarily concerned, is the one which should deal with the relationship.

Whether custody has sufficient characteristics in common with such gencral concepts as marriage, legitimacy, and adoption so as to be properly included with them as falling within the general scope of the term "status" could very well be questioned. Custody proceedings do not have as their purpose creation or recognition of an aggregate of legal relations, but rather a judicial determination of conflicting claims to the physical control and care of the child. These claims would normally be incidents of the parent-child relationship, and under ordinary circumstances there would be no occasion at all for their assertion in court. It is when the circumstances become abnormal, as where the parents are separated, or there is a divorce, or the parents are allegedly unfit, or are dead, that a situation for judicial cognizance arises. If the case were merely one for determining the merits of the conflicting claims as between the immediate parties, there would be no particular reason for departing from usual concepts of jurisdiction in personam; but the very abnormality of the situation brings into play the further idea that in making his decision, the trial judge should be guided not so much by legalistic formulae as by considerations which have a bearing upon the ultimate interests of the child. Actuated by this thought, a number of courts have held that the interests of the child can be adequately protected at the place where it actually resides and that jurisdiction exists there even though that place may not be the child's technical domicil. ${ }^{39}$

I 82 S.E. 845 (1935); Durfee v. Durfee, 293 Mass. 472, 200 N.E. 395 (1936); Rest., Conflict of Laws $\$ 32$ (I934); cf. MrcAdams v. MIcFerron, r8o Miss. 644, I78 So. 333 (I93\$) (a decree granted in Tennessee was held not to be entitled to recognition because the domicil of the child was in Mississippi with the grandmother to whom custody had been previouslygranted); Minick v. Minick, I I I Fla. 469 , I 49 So. 483 (I933) (the father's domicil fixes that of the child when the mother and child are wrongfully living apart from him).

$3^{5}$ Rest., Conflict of Laws $\$ \S$ II 7, I4\$ (1934). Duryea v. Duryea, 46 Idaho 5I 2, 269 Pac. 987 (r928), in which the child was domiciled in Idaho, living there with its father. Suit was brought by the mother in Nevada where actual service was had on the father. Full faith and credit was refused, but it might be noted that the child was not in Nevada and actually resided with its father. In Kline $v$. Kline, 57 Towa ${ }_{3} S 6$, Io N.W. $S_{25}$ (IS8I), the foreign state was neither the domicil nor the residence of the child, who, because it was living with the mother in Iowa, was found to be domiciled in that state.

39 Kenner v. Kenner, I 39 Tenn. 2 Ir, 201 S.WF. 779 (I9I7); Sheehy v. Sheehy, 88 N.H. 223, IS6 Atl. I (1936); Finlay v. Finlay, 240 X.I. 429, I48 N.E. 624 (I925); Goldsmith v. Salkey, I 5 S.IV. (2d) 77 S (Tex. Civ. App. 1937); White v. White, 77 N.H. 26, 86 Atl. 353 (1913). 
In some of the cases emphasis has also been upon the importance of the presence of the child within the territorial limits of the decree-granting state, an analogy being sometimes made to in rem jurisdiction over property. ${ }^{40}$

In spite of the fact that contested custody proceedings so frequently take on the aspects of an acrimonious family quarrel in which the parents and sometimes other relatives hurl recriminations back and forth, as though their interests were alone involved, it is universally agreed that the principal objective of the court should be to make a decision which tends best to safeguard and promote the welfare of the child.4I As a consequence, whatever differences there may be between custody and adoption in other respects, the guiding principles in the two proceedings are much the same, namely, protection of the child against the possibility of continuing in or entering an environment which may have an adverse effect on its social, psychological, and physical welfare. It would seem, then, that demarcation of the lines which would limit permissible exercise of judicial power in custody proceedings should, as in adoption proceedings, be drawn from the point of view of the ability of the court entertaining them to make such an investigation of the facts as will enable it to act for the best interests of the child. As pointed out in connection with the discussion of adoption, a court sitting at the actual residence of the child or at the residence of the petitioner, if in the latter case there is personal jurisdiction over the child and over the person then having actual control of it, is adequately prepared to make the proper inquiry.

But irrespective of the question of jurisdiction, the matter of recognition of the continuing effect of a foreign custody award involves a further problem which arises from the fact that custody is never final. The decree purports to make an award on the facts as they exist at the time, and the power is reserved to change, amend, or alter the original order as new facts arise. ${ }^{42}$

The temporary nature of a custody decree has led at least one court to take the position that a foreign award is not entitled to full faith and cred-

${ }^{40}$ In the Duryea and Kline cases, discussed in note 38 supra, the absence of the child from the decree-granting state was stressed as much as lack of domicil. In Kenner v. Kenner, 139 Tenn. 2II, 20I S.W. 779 ( 1917 ), it was said "when the mother has personal custody [of the child], .... the control of the child is as truly placed with the court as is that of property attached in a suit to procure alimony." Cf. the general language of White v. White, 77 N.H. 26, 86 Atl. 353 (x913), and Sheehy v. Sheehy, 88 N.H. 223, I86 Atl. I (1936). But cf. Minick v. Minick, II I Fla. 469 , I 49 So. 483 (I933); Bourn v. Hinsey, I 34 Fla. 404 , I83 So. 6 I $_{4}$ (1937); Person v. Person, I72 La. 740, 135 So. 225 (1931).

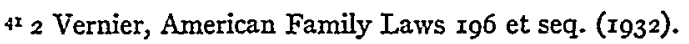

42 Ibid., at r94. 
it. ${ }^{43}$ But most courts have held that the decree will be given recognition insofar as there has been no change in conditions since the date of its rendition. ${ }^{44}$ A change in conditions makes it permissible, however, to go into the issue of fitness anew and to enter another decree without regard to the earlier action of the foreign court. It is believed that the courts in a majority of instances have shown considerable reluctance to change the relations fixed by the foreign decree, but, unfortunately, the term "change in conditions" is sufficiently broad to make it possible for a court to escape what it might otherwise feel to be an obligation to recognize an earlier award as still effective through resort to the simple expedient of requiring little evidence of change. And there are cases in which very little indeed seems to have sufficed to justify undertaking to make a new disposition of the child. As a result, while most of the courts state that the foreign decree will be disturbed only upon a showing of changed conditions, there are just enough cases in which there has been a new award on what seems to have been slight proof to make it hazardous to predict what the judicial reaction in a particular situation might be. 45

Stability of environment is clearly one of the important factors in the well-being of a child. As such, it would seem to be something which is worth striving for. The daily press from time to time gives accounts of abductions by recalcitrant parents or other relatives, who, by removing a

${ }^{43}$ In re Bort, 25 Kan. 308 (I88x). But cf. Wear v. Wear, r30 Kan. 205, 285 Pac. 606 (I930) • See also Sparkman v. Sparkman, 2I7 Ala. 4I, II4 So. 580 (I927); In re Alderman, I57 N.C. 507, 73 S.E. I26 (rgrr); Commonwealth ex rel. Rogers v. Daven, 298 Pa. 4r6, r48 Atl. 524 (1930).

44 Hamilton v. Anderson, 776 Ark. 76, 2 S.W. (2d) 673 (r928); Titcomb v. Superior Court, 220 Cal. 34, 29 P. (2d) 206 (I934); People v. Schaedel, 340 Ill. 560 , x73 N.E. I72 (I930); Barnett v. Blackeley, 202 Iowa I, 209 N.W. 4 12 (I926); Ex parte Peddicord, 269 Mich. r42, 256 N.W. 833 (I934); Ansorge v. Armour, 267 N.Y. 492 , r96 N.E. 546 (I935); Griffin v. Griffin, 95 Ore. 78, I87 Pac. 598 (r920); Goldsmith v. Salkey, rr5 S.W. (2d) 778 (Tex. Civ. App. r937).

${ }_{45}$ One would like to believe, along with the author of the note, Effect of Custody Decree in a State Other Than Where Rendered, 8r Pa. L. Rev. 970 (I933), that the large majority of courts have required strong proof of such a change in conditions as would make a new award imperative. The following citations are intended to be illustrative, not exhaustive: Sparkman v. Sparkman, $2 I_{7} \mathrm{Ala}$. $4 \mathrm{I}$, II4 So. 580 (I927) (all the issues were re-examined but the court expressed disapproval of harassing litigation); In re Livingtson, I08 Cal. App. 716, 292 Pac. 285 (1930) (a Wisconsin decree was left undisturbed because of failure to show new conditions); Evans v. Taylor, 128 S.W. (2d) 77 (Tex. Civ. App. 1939) (proof of changed conditions was treated as insufficient to justify a new decree); Ansorge v. Armour, 267 N.Y. 492, x96 N.E. 546 (I935) (slight proof was held to be insufficient); Hachez v. Hachez, I24 N.J. Eq. 442, I A. (2d) 845 ( 1938 ) (temporary presence was not enough to justify interference); Motichka v. Rollands, I44 Wash. 565,258 Pac. 333 (1927) (temporary nature of sojourn sufficient to preclude a new investigation); cf. Hamilton v. Anderson, 176 Ark. 76, 2 S.W. (2d) 673 (I928); People v. Schaedel, 340 Ill. 560 , I73 N.E. I72 (r930); Ex parte Peddicord, 269 Mich. I42, 256 N.W. 833 (r934); Cooke v. Cooke, 67 Utah 37I, 248 Pac. 83 (r926). 
child to a friendly jurisdiction, hope to hold it in defiance of an earlier custody decree. Lawyers are familiar enough with suits which, after the removal of a child to another state, are brought by a litigant who has been disappointed in the earlier proceedings. ${ }^{46}$ The disturbing effect upon a child of an unnecessary change of environment which may be wrought through resort to new judicial proceedings in a second state is obvious. However, stability could be secured if the courts adopted a liberal view of jurisdiction to entertain custody proceedings and then disturbed the foreign decree only upon convincing proof that conditions have become such as to make it undesirable for the child to remain in the environment fixed by the earlier decree. A broad jurisdictional concept based upon the ability of the foreign court to fulfill its functions, rather than upon a theoretical concept of state interest in its domiciliaries, would minimize the possibility of attack on foreign decrees on purely technical grounds. Refusal by the courts to disregard the continuing effectiveness of the foreign decree in the absence of clear proof of necessity in order to safeguard the child would tend to make it futile for a disappointed litigant to attempt to retry issues which presumably have already been adjudicated.

\section{CONCLUSIONS}

Insofar as decisions by the Supreme Court of the United States are concerned, there seems to be no case fixing the limits of permissible exercise of judicial power in either adoption or custody proceedings. Nor is there any case specifically dealing with the full faith and credit which must be accorded foreign custody awards or decrees under the Constitution. It is not likely, however, that the Court will ever compel recognition by a state court of the continuing effect of a foreign decree when a new order has been entered at the forum because of "changed conditions." 47 It might also be recalled

${ }^{4}$ See Effect of Custody Decree in a State Other Than Where Rendered, 8r Pa. L. Rev. 970 (x933), giving the background of Evens v. Keller, 35 N.M. 659, 6 P. (2d) 200 (x93 I), and State v. Keller, 36 N.M. 8I, 8 P. (2d) 786 (I932) (an extreme instance of a disappointed litigant attempting to evade the effects of a decree originally granted in Missouri). The author of this note would, in order to secure greater recognition of custody decrees, broaden the content of "domicil of children" by making it include residence of the child and then would insist upon domicil as a jurisdictional requirement. While actual residence with a parent does suffice for domicil in a number of states (cases cited note 3 I supra), it may not in all. Under the generally accepted rules, residence with persons not parents never suffices to establish a separate domicil for children while the parents are living. Upon the death of both parents, residence with grandparents may be enough to establish the child's domicil; but not residence with others, such as an uncle, aunt, etc. Rest., Conflict of Laws $\$ 39$ (I934).

${ }_{47}$ Attention should be called, however, to Yarborough v. Yarborough, 290 U.S. 202 (1933), in which the question was the effect of a prior adjudication of the duty of a father to support a child. Adjudication at the domicil of the father was held to preclude subsequent suit at the 
that it has been held that a foreign adoption need not be given effect if local policy is thought to prevent it. ${ }^{8}$ It would seem, therefore, that from a practical point of view, recognition of foreign adoption or custody is a matter which is largely within the control of the state courts. They have the power to withhold recognition through resort either to the device of "changed conditions" or to the concept of local policy without going into jurisdictional questions.

Since, however, most of the courts have been, at least in their expressions to this effect, on the liberal side in according full faith and credit to foreign custody and adoption awards or decrees, the matter of jurisdiction has been a frequent issue. But the cases as a whole fall far short of indicating, as some would have it, widespread acceptance by the American courts of a single uniform jurisdictional standard for either proceeding. Consequently, disregarding temptations to give the cases wished-for meaning, it can at least be said that jurisdiction to adopt or to award custody is a concept, the American contours of which have not as yet been definitely drawn.

One method of approach in fixing the limits of state power where status is involved would be to assume that underlying similarities between the different species of status are such as to require the position that because for some species domicil has been uniformly held to be the important jurisdictional factor, it should, by way of analogy, be treated as all important for the others. In this connection judicial decisions with respect to divorce and legitimacy lend color to the thought that control over status belongs to the domiciliary state.

But the cases, which uniformly make domicil a necessary factor for jurisdiction to divorce, while they do involve state power over status, are not particularly helpful. Unlike the case in adoption and custody proceedings, a court in dissolving a marriage exercises no discretionary function. Upon proof of the facts fixed by the law at the forum as grounds for divorce the marriage is dissolved as a matter of course. Furthermore, divorce involves persons who, because they are sui juris, are capable of choosing their own homes or places of abode so that domicil and actual residence normally coincide. Domicil as a result of actual residence is much more persuasive as a basis for jurisdiction than domicil which, because of the method em-

domicil of the child. In the course of the opinion it was stated that the status of a child is ordinarily determined by the law of the father's domicil. On the matter of full faith and credit to be given judgments and decrees which are not final, see Rest., Conflict of Laws § 435 (I934). As to custody decrees see ibid., at $\S$ I 47 .

$4^{8}$ See note 20 supra. 
ployed in determining its location for minors, may be at a place with which the minor has no factual connection whatever. In addition, the considerations of convenience and expediency which are involved in marking the lines of permitted jurisdiction to divorce are not the same as those where the right to control children is in issue. ${ }^{49}$

Judicial reaction to the problem of the proper law to control legitimacy also affords but scant analogy to draw upon when adoption and custody are involved. Assignment to a person of legitimate character, like divorce, is not a matter for the exercise of judicial discretion. The happening of some particular event or events which are prescribed by law and the occurrence of which is within the control of the parent automatically confers legitimate standing. The cases have involved the ability of a child to succeed as legitimate heir, and it seems natural enough for his legitimate character with respect to the parent through whom he claims as heir to be controlled by the law of the place where the parent lived when the acts conferring legitimacy took place..$^{50}$

The position might be taken that the underlying reason for the judicial practice of giving controlling effect to the law of the parent's domicil in the legitimacy cases lies in the fact that the parent's act or acts makes the child a legal member of his family. Whether the parent should be permitted to bring his natural child into his legal family, so the argument might run, is a matter of concern to the state of the parent's domicil because that is where his family normally resides. Since adoption brings a stranger in blood into the family, the position could also be taken, by way of analogy to the legitimacy cases, that the legal effect of the acts of the adoptive parent should be subject to the control of the state where the parent is domiciled. It might even be contended that because control and care of children involve family relations, power over custody belongs to the state with which these matters are the most closely identified.

But an argument by way of analogy to the situations which exist with respect to divorce and legitimacy fails to make allowance for the fact that at least in the case of one species of status, considerations of expediency have induced the courts to minimize the importance of domicil as a jurisdictional factor.

The family significance of marriage is obvious. Nevertheless it is uni-

49 The Supreme Court cases include Andrews v. Andrews, I88 U.S. I4 (1903) (one of the parties must have a bona fide residence and domicil in the decree-granting state); Atherton v. Atherton, I8I U.S. I55 (IgOI); and Haddock v. Haddock, 20I U.S. 562 (IgO6) (dealing with the full faith and credit to be given sister-state divorces). See also Bingham, The American Law Institute v. the Supreme Court, 2 I Corn. L.Q. 393 (I936).

${ }^{{ }^{5}}$ See notes 9, IO, II, and I2 supra, for cases dealing with legitimacy. 
versally held that the formalities of the ceremony are controlled by the law of the place of celebration, which place need not be the domicil of either party. Even when the question is one of capacity or of the effect of some express prohibition at the domicil, the decided judicial tendency is to uphold the marriage if it does not violate the law of the place of celebration. The only exception is where the marriage is one which runs counter to an unusually strong sense of social policy of the state where the parties habitually reside, and then there is never any thought that the marriage need be celebrated at any particular place. ${ }^{5 x}$

What has happened in the case of marriage is that most courts, including those at the domicil, have come to the conclusion that ordinarily it is better social policy to treat the marriage as valid if it conforms to the law at the place of celebration than to give controlling effect to a local rule of law which might invalidate it and thus render the parties guilty of illicit cohabitation and so make the offspring illegitimate. Here, social consequences rather than fine-spun theories of power at the domicil or of interest at the domicil in family relations have influenced results.

As a matter of fact a number of different factors have influenced the courts in shaping their concept of the power of a state, through the operation of its laws or through the action of its courts, to create the various sets or aggregates of relations which are ordinarily included within the scope of the term "status." Tradition and the voice of Justice Story have been an important influence. At times an instinctive feeling that where status is involved there should be a closer connection with a state than exists through mere temporary sojourn has, as in the divorce cases, been persuasive. But social objectives and convenience have also played their part, so that, as in the case of marriage, traditional ideas have been disregarded when it has seemed expedient to do so. As a result the concept or concepts of "jurisdiction" to create status, instead of being cut along the lines of one single pattern to be applied consistently, have been cut into different patterns according to the particular kind of status involved.

The fact that provision is now made for adoption throughout the United States has materially reduced the possibility that liberal recognition of a foreign adoption will result in foisting upon a state a relationship of which it disapproves. The ever increasing tendency toward even closer supervision than is implied in mere judicial approval is reducing this possibility to a minimum. Hence the important consideration in connection with jurisdiction over adoption is that the proceedings take place under

${ }_{5 x}$ Cf. Rest., Conflict of Laws $\S \S$ I2I-34 (I934); In re Miller's Estate, 239 Mich. 455, 2I 4 N.W. 428 (r927); Johnson v. Johnson, 57 Wash. 89, xo6 Pac. 500 (Igro). 
circumstances which permit opportunity for fulfillment of the purposes of judicial investigation and control. Then, if this condition is fulfilled, the adoption should be recognized everywhere as valid so as to assure stability of environment. The same considerations hold true for custody.

Domicil is a technical concept. ${ }^{22}$ While ordinarily domicil and actual residence coincide, the domicil of a person can be physically far removed from the place where he actually lives. This is particularly a possibility in the case of children whose domicil, because they are not sui juris, is dependent upon the domicil of others. Consequently, if the thesis that power with respect to status depends upon domicil is carried to its logical conclusion, adoption and custody proceedings could take place in a state with which the parties have only a connection based on a mere legal technicality..$^{53}$

It is submitted that a concept of judicial jurisdiction over matters as closely identified with child welfare as are custody and adoption should be based on factors which relate to the ability of a judge to fulfill the functions for which judicial intervention is provided. These functions consist primarily of the exercise of discretion in such a manner as to provide a proper environment for the child whose custody or adoption is in issue. It is believed that the purposes of judicial control can be best fulfilled at the actual residence of the child or at the residence of the petitioner because a court sitting at either place is likely to have greater facilities for proper investigation than the courts at any other place. It is possible, however, that conditions may be such as would enable the courts at some other place to make the proper investigation. But, in any event, the boundary lines of jurisdiction to adopt or to award custody, if they are to be at all satisfactory, should be drawn with the thought in mind that the objective of the proceedings in both instances is the welfare of the child. Technical concepts of jurisdiction based on domicil and upon theoretical interest by a state in its own domiciliaries seem far removed from problems of child welfare.

52 Rest., Conflict of Laws § 9 et seq. (I934).

53 As to domicil of minors see Rest., Conflict of Laws $\$ \S 30-39$ (r934). Suppose, for example, that the child is living with an aunt with whom it has been left by its parents. Suit for divorce is brought in another state, which is also the domicil of the father. That state would be the technical domicil of the child. Rest., Conflict of Laws $\$ 30$ (I934). Would the court there be in as good a position to go into the matter of custody or of adoption as would a court in the state where the child is living with the aunt? 